\title{
The implementation and effect of sasi on coconut (Cocos nucifera L.) harvest products in southern Buru, Indonesia
}

\author{
Evelin Tuhumuri ${ }^{1,2, *}$, Retno Peni Sancayaningsih ${ }^{3}$, Bambang Setiaji ${ }^{4}$ and Sunyoto Usman ${ }^{5}$ \\ ${ }^{1}$ Student Graduate Program of Faculty of Biology, Gadjah Mada University, Sleman, Special Region of Yogyakarta, 55281, Indonesia \\ 2 Department of Biology, Faculty of Mathematics and Natural Sciences, Pattimura University, Ambon, Maluku, Indonesia \\ ${ }^{3}$ Ecology and Conservation Laboratory, Faculty of Biology, Gadjah Mada University, Sleman, Special Region of Yogyakarta, 55281, \\ Indonesia \\ ${ }^{4}$ Departments of Chemistry, Faculty of Mathematics and Natural Sciences, Gadjah Mada University, Sleman, Special Region of \\ Yogyakarta, 55281, Indonesia \\ 5 Sociology Department, Faculty of Social And Political Sciences, Gadjah Mada University, Sleman, Special Region of Yogyakarta, \\ 55281, Indonesia
}

Received 1 February 2019 - Accepted 10 December 2019

\begin{abstract}
Coconut (Cocos nucifera L.) is common plant for the Moluccan farmers to apply local wisdom in cultivation, called sasi. This study describes sasi implementation of coconut cultivation in South Buru and its effects on the quality of the coconut harvest. The research was conducted by field observation and interviews. Data were obtained from coconut trees aged 16-25 years and $>30$ years. There are two common methods of cultivation through sasi, religion-based permission (local church) and traditional sasi. Both forms of sasi have different indications. On the basis of the sasi system, coconut plantations cannot be penetrated for six months (a spell prohibiting access to the crop) and harvesting only takes place after the end of the sasi period (avoiding any risk of theft of the fruit). Yields on the 16-25-years-old trees had a weight of endosperms of 243-378 $\mathrm{g}$ and a thickness of the coconut endosperm of 9.2-12.2 mm over the monitored 10-18 months fruit age period, each showing a bell-shaped variation with a maximum for about 13 months old fruits. Yields on $>30$-years-old trees group showed the same pattern. Thus, although sasi is useful for protecting the coconut fruit before harvesting, the implementation of coconut sasi for six months ultimately decreases the quality of the crops and postpones the best harvest time. Therefore it is recommended that the implementation of coconut sasi in South Buru be adjusted with the biological timing of coconut ripening.
\end{abstract}

Keywords: coconut cultivation / coconut sasi / local wisdom / quality of crops / wisdom in cultivation

Résumé - La mise en œuvre et les effets du système de croyances "sasi " sur la récolte de noix de coco (Cocos nucifera L.) dans le Sud de Buru (Indonésie). La noix de coco (Cocos nucifera L.) est une plante commune utilisée par les agriculteurs de l'archipel des Moluques en Indonésie pour appliquer un système de croyances appelé sasi qui incarne les principales règles légales de cette société. Cette étude décrit la mise en œuvre du système sasi dans la culture de la noix de coco dans le Sud de Buru, en Indonésie, et ses effets sur la qualité de la récolte de noix de coco. La recherche a été menée via des observations de terrain et entretiens. Les données ont été obtenues à partir de cocotiers âgés de 16 à 25 ans et de plus de 30 ans. Il existe deux méthodes de culture communes : le système sasi avec permission religieuse (église locale) et le sasi traditionnel. Les deux formes de sasi ont des indications différentes. Sur la base du système sasi, les plantations de noix de coco ne peuvent être pénétrées pendant six mois (un sort interdisant l'accès à la culture) et la récolte n'a lieu qu'après la fin de la période sasi (évitant tout risque de vol des fruits). Les rendements des arbres âgés de 16-25 ans montrent un poids d'endospermes de 243-378 g et une épaisseur de l'endosperme de noix de coco de 9,2-12,2 mm durant la période de suivi (fruit de 10 à 18 mois), avec une variation en cloche et un maximum atteint lorsque les fruits ont de l'ordre de 13 mois. Les rendements du groupe des arbres de plus de 30 ans ont montré la même tendance. Ainsi, bien que le sasi soit utile pour

\footnotetext{
* Correspondence: etuhumuri@yahoo.co.id
} 
protéger le fruit de la noix de coco avant la récolte, la mise en œuvre du sasi pendant six mois diminue finalement la qualité des cultures et retarde la meilleure période de récolte. Par conséquent, il est recommandé que la mise en œuvre du sasi de noix de coco dans le sud du Buru soit adaptée au moment biologique de la maturation de la noix de coco.

Mots clés : culture de la noix de coco / sasi / croyance / qualité des cultures

\section{Introduction}

Indonesia has diverse ethnicities and cultures, and each tribe has local wisdom in the management of natural resources (Marfai, 2012). Although the flow of modernization is growing rapidly, many local pearls of wisdom are still maintained due to the benefits associated with traditional values, including benefits to agriculture. Almost every region has local wisdom in managing land, crops and agricultural products. One of the most famous local wisdom in the Maluku region of Indonesia is sasi, which means prohibition. Sasi is a prohibition on the harvesting of specific natural resources, on land or in the oceans, over a period depending on the type and development of the natural resource population (Kissya, 1993). During the term or period of the ban, the harvested natural resources are permitted the opportunity to reproduce (Kissya, 1993; Henley, 2008). Therefore, sasi aims to prevent theft of a crop before the harvest time, thereby leading to more significant quantities of fruit at harvest time.

Coconut (Cocos nucifera L.) is one of the plantation commodity in Indonesia. The coconut plantation area in Indonesia is about 3653167 ha with the production of 2870739 ton. Ninty-nine percent of total area is people's plantation with a production of $98.87 \%$ in total production in Indonesia (Hendaryati and Arianto, 2017). Coconut is a part of Indonesia life. Coconut is a tree of life because of all parts are useful in life (Simpala and Kusuma, 2015). Coconut endosperms are used for making copra and coconut oil. Coconut stems are used for building materials and firewood. Coconut fibers, shells and tree roots are also used as firewood. Parts of palm fronds and fibers are used as handicraft materials. It shows that coconut has a high economic value.

Coconut is the most cultivated plant by the people on the Southern Coast of Buru Island, Maluku (Badan Pusat Statistik, 2017). The primary product of processed coconut in the area is copra. The plantation system is farmer plantation with traditional cultivation until now. The knowledge of cultivation is a legacy from generation to generation. The local wisdom in the cultivation in Buru Island is sasi. Sasi means prohibition. Sasi in coconut farm or coconut sasi means a prohibition to take the coconut in a period. The farmers apply the local wisdom of coconut sasi because often the coconut plantation is located at some distance from where the farmers live and commonly, the period is 6 months.

Coconut includes annual crops that bear fruit throughout the year (Simpala and Kusuma, 2015). Coconut trees entering productive age can produce $12-15$ bouquets a year, which means that a coconut tree produces a wreath almost every month. The coconut flower is monoecious and protandrous (Thampan, 1981; Soedijanto and Sianipar, 1984; Dransfield et al., 2008). The fertilized flower will give a fruit that can be harvested at $12-13$ months or $12-14$ months after blooming.
Meanwhile it depends on the environmental conditions. By the coconut bouquets growth, there will be ripe coconuts which are ready to be harvested (Thampan, 1981; Soedijanto and Sianipar, 1984). Thus, the coconut can be harvested almost every month.

Generally, the implementation of coconut sasi is meant to ensure the safety of the coconut fruit before harvest. However, the effect of coconut sasi on the quality of coconut harvest remains unknown. The purpose of this study is to describe the implementation of coconut sasi in South Buru and its effect on the quality of the coconut harvest.

\section{Materials and methods}

\subsection{Location and time of study}

The research was conducted in Waemulang, Leksula, Waenalut and Namrole villages, South Buru District, Maluku Province, Indonesia. The study was conducted in September 2015-May 2016.

\subsection{Research area and sampling method}

The scope of this study was the farmers and coconut after sasi. There were 25 farmers as key informants who were recommended by the customary leaders, communities and priests in the research area. The farmers were the owner of coconut plantation who implemented sasi and capable to answer the questions. The selection of vital informants was based on their experience as coconut farmers without including age restrictions, education, or other social status limitations. A semi-structured interview with the triangulation principle was used to compare information from one resource with information from other sources (Mitchell et al., 2010). Field observations were conducted to observe coconut sasi implementations and the activities of the coconut farmers. Data on coconut sasi practices and farmers' knowledge about coconut were obtained using a participatory local appraisal (PRA) approach (Mitchell et al., 2010). The collection of coconut harvest data was obtained only from the coconut plantation in Namrole because the distance between the four villages was very large and the sea transportation available is limited.

\subsection{Population and sample size determination}

The harvesting periods of the four villages occurred almost simultaneously. The data of coconut harvest was taken from two groups based on tree age: 16-25 years (adult/productive) and $>30$ years (old/assumed more or less production).

Five trees from each age group were randomly selected. Each selected sample tree was marked using ribbons and color 
markers in sequence from the youngest to the oldest. The marking of bunches and coconuts was done during the cap or before harvest. Marking was intended to determine the age of the fruit when it was harvested. The total number of coconut in this study was 114 fruits.

Coconut was harvested by farmers by climbing trees using notches on tree trunks as a foothold. Farmers used machetes to cut ripe coconuts from bunches. The harvested fruits were then grouped according to their age. From each fruit-age group, six coconuts were picked. The total weight of fruit, endosperm (flesh of fruit) weight, and coconut water $(\approx \mathrm{mL})$ were measured using digital scales. The thickness of the endosperm was measured using a digital caliper.

\subsection{Analysis method}

The data were analyzed descriptively based on the results of the observations and interviews with credible farmers. The description explains the research object based on observation.

\section{Results and discussions}

\subsection{Coconut sasi practices in South Buru}

Sasi in Buru, called sihit, has long been implemented in South Buru. The informants could not recall when sasi started, but they claim that the current method of sasi is a tradition or cultural heritage of their ancestors. There are two ways to implement coconut sasi, through church sasi and traditional sasi. Church Sasi is based on spiritual support from religious institutions, of which Christian is the dominant religion in this area. Conversely, traditional sasi is based on the personal beliefs of the coconut plant owner by following the habit of his ancestors. Interviews showed that $64 \%$ of resource persons used church sasi, $8 \%$ used traditional sasi, and $12 \%$ used a combination of church and traditional sasi. The remaining $16 \%$ no longer used sasi because they have a residence near to their coconut cultivation to supervise it directly (Tab. 1).

The resource persons who used sasi church and traditional sasi simultaneously gave the reason that traditional sasi was used to strengthen the church sasi. They believe that using a combination of church and traditional sasi is more potent for preventing coconut stealing.

The mechanism of coconut sasi implementation begins with the closed sasi period and ends with the open sasi period. Closed sasi is a sign of the enactment of sasi or the ban of coconut stealing. On the other hand, open sasi is a sign of the end of the sasi period or the lifting the ban, which is then followed by harvesting the coconut. Closed sasi and open sasi are both based on church sasi and marked with a religious ritual led by a local church priest in Sunday worship at church. Following this, the sasi sign (sign of ban) is installed by the coconut farmers. The church's signature informs readers that the coconut tree on the land has been disseminated by the owner using church sasi (Fig. 1).

Unlike the church sasi, closed sasi and open sasi are based on traditional sasi, which is not indicated by a custom ritual or traditional ceremony. Custom signs can be directly installed by the owner of the garden based on his traditional belief. Custom
Table 1. How farmers secure their coconut cultivation.

\begin{tabular}{llll}
\hline Cultivation secure & Implementation & $\begin{array}{l}\text { Total } \\
\text { (persons) }\end{array}$ & $\%$ \\
\hline \multirow{3}{*}{ Implementing coconut sasi } & Church sasi & 16 & 64 \\
& Traditional sasi & 2 & 8 \\
Without sasi & Combined sasi & 3 & 12 \\
Total & Directly securing & 4 & 16 \\
\hline
\end{tabular}

marks are made of wooden stems coupled with midrib and coconut leaves, fruit bunches and coconut fruits or other parts of the coconut plant as a sign that the area is being dissipated by the owner. There are also traditional markings coupled with other objects believed to have magical powers, such as red cloth, bottles or packages containing a plague or reinforcement spell to injure the person who stole the coconut (Fig. 2). The current generation still preserves the custom marks of sasi used by their ancestors.

The duration of the sasi period is determined by the farmer or the owner of the coconut farm. From resource persons using coconut sasi, $76.19 \%$ impose a period within six months. Similar to those who use sasi, $75 \%$ of non-sasi user farmers cultivate the coconut within six months. The frequency of harvesting data conducted by the resource persons is presented in Table 2. The six-month planting and six-month harvesting periods are thought to provide greater benefits because it produces ripe coconuts in better quality. If farmers have not been able to harvest coconuts for some reason, then the duration of the sasi can be extended for more than six months.

During the duration of the sasi, the owners of the coconut farm and other surrounding people are prohibited from taking or stealing coconut, even though ripe coconuts fall under the trees. Violation of a sasi is considered a sin that may result in the offender suffering from illness or misfortune, and is based on spiritual and traditional beliefs. Church sasi users believe that it is God who guards, protects and blesses the coconut plantation so that they may enjoy good results. Any man who steals from his garden is believed to be punished by God. Traditional sasi users believe any person who steals from his garden would be punished as he wanted or from the plague placed on the traditional sasi mark.

The people of South Buru strongly abide by the ban and believe in the punishment of stealing from coconut farms as long as they are under the sasi period. According to Henley (2008), the effectiveness of the sasi partly lies in the belief that illness and other misfortune will befall the offenders. The belief is still embraced by the people in South Buru to date, so rarely a violation of coconut sasi occurs.

Coconut sasi becomes an effective means to secure the coconut fruit before harvest period. In addition to securing coconut, the resource persons acknowledged that the implementation of coconut sasi provides other benefits of feeling calm and believing that sasi tradition will preserve their ancestors' culture. Similarly, all informant farmers stated that the coconut sasi tradition must be preserved because it is the cultural heritage of their ancestors and is effective for securing coconut products. 

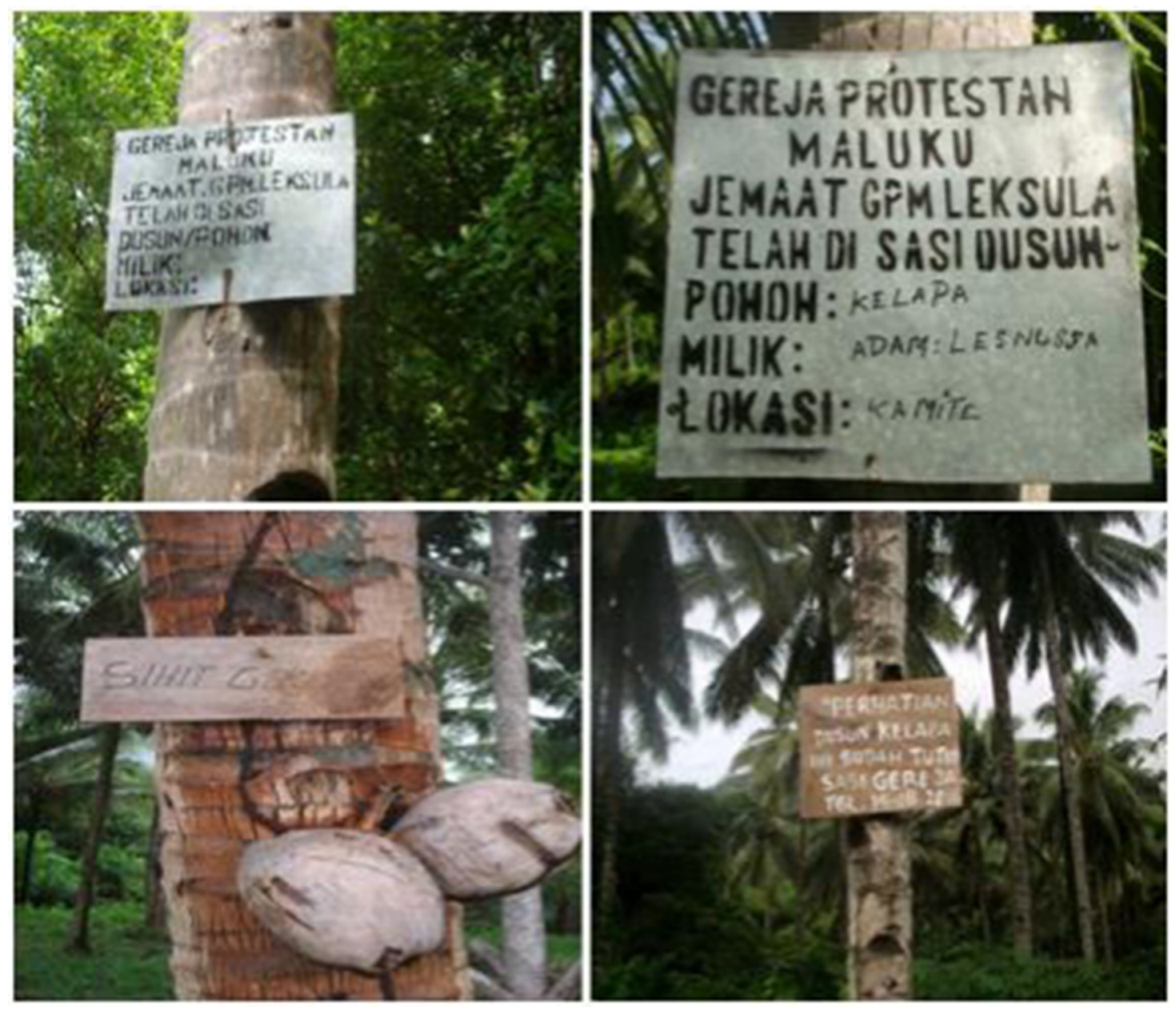

Fig. 1. Examples of signs used in coconut church sasi.

Sasi is a norm as well as the rule for the people of South Buru in terms of respecting the property of others by involving spiritual and traditional beliefs. Specifically, Keraf (2010) described that traditional wisdom is a form of knowledge, belief, understanding or insight and that the customs or ethics that guide human behavior in an ecological community are lived, practiced, taught and passed from one generation to the other, which simultaneously shapes the pattern of daily human behavior in relation to their surroundings. It resembles a religion that guides people in attitudes and actions, both in the context of everyday life and human civilization (Keraf, 2010).

\subsection{Harvesting frequency and fruit-age variation}

The implementation of coconut sasi for six months means that the frequency of harvesting is twice a year. The frequency of harvesting of coconuts in South Buru is different from the frequency of harvesting of coconuts in other places. For instance, in Ngilngof Village in the Southeast Maluku Regency, coconut sasi is within 3-4 months, which means the harvest can be done 3-4 times a year. In Sri Lanka, coconut is generally harvested every two months or six times a year (Pathiraja et al., 2007). In Kerala, India, and in Java, Indonesia, coconut is harvested once a month (Thampan, 1981; Soedijanto and Sianipar, 1984).
The coconut fruit harvested by this study varied in fruit age. The coconut tree group aged 16-25 years obtained fruit that was 10-18 months of age (Tab. 3). The coconut tree group aged $>30$ years obtained fruit that was aged 9-18 months (Tab. 4). Yields from the trees aged $>30$ years had a greater fruit-age variation than crop yields from the trees in the 16-25 years group.

According to Thampan (1981), Soedijanto and Sianipar (1984), there are three levels of fruit maturity in a coconut crop: unripe fruit ( $<12$ months), ripe fruit (12-14 months) and overripe fruit ( $>14$ months). Some of the fruits that are too ripe have started to remove the buds. The variation in the level of maturity of the harvested coconuts shows that the farmers do not have sufficient knowledge regarding the exact age of the ripe and harvested coconut. The lack of knowledge about the maturity of the fruit and the desire to get more results leads the farmers to harvest unripe coconuts.

As a raw material of copra, ripe coconut harvested once a month or at most every two months can improve the quality of copra (Dransfield et al., 2008). Coconuts harvested under 12 months result in poorer quality (Soedijanto and Sianipar, 1984; Dransfield et al., 2008). Harvesting should be done immediately when the fruit is ripe, since the fruit will soon have shoots for re-planting as a tree, rather than a consumable fruit (Darwis, 1986). 

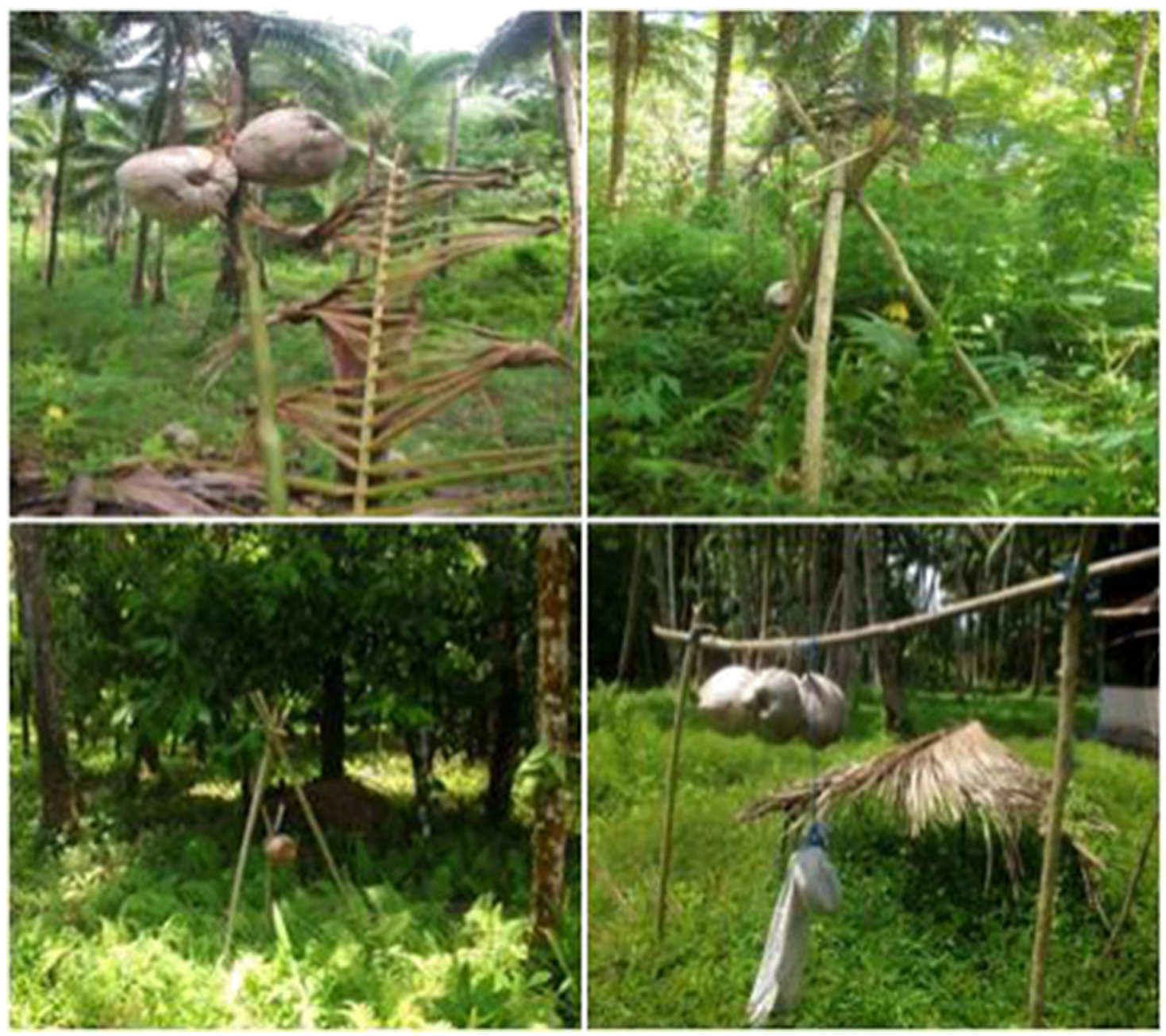

Fig. 2. Custom signs used in traditional coconut sasi.

Table 2. Coconut harvesting frequency.



\subsection{Quality of coconut}

Table 3 shows that the coconut harvest from trees aged 16-25-years-old-trees had total weight fruit and endosperms weight of $1472 \pm 239 \mathrm{~g}$ and $301 \pm 19 \mathrm{~g}$ (10 months); $1522 \pm 176 \mathrm{~g}$ and $345 \pm 55 \mathrm{~g}$ (11 months); $1422 \pm 53 \mathrm{~g}$ and $364 \pm 53 \mathrm{~g}$ (12 months); $1164 \pm 157 \mathrm{~g}$ and $378 \pm 76 \mathrm{~g}$ (13 months); $1132 \pm 184 \mathrm{~g}$ and $360 \pm 107 \mathrm{~g}$ (14 months); $997 \pm 80 \mathrm{~g}$ and $323 \pm 46 \mathrm{~g}$ (15 months); $804 \pm 88 \mathrm{~g}$ and $271 \pm 39 \mathrm{~g}$ (16 months); $794 \pm 67 \mathrm{~g}$ and $243 \pm 28 \mathrm{~g}$ (17 months); $820 \pm 214 \mathrm{~g}$ and $273 \pm 62 \mathrm{~g}$ (18 months). Meanwhile, the endosperms thickness and water volume for each fruit age were about $10.6 \pm 0.6 \mathrm{~mm}$ and $304 \pm 59 \mathrm{~mL}$ (10 months); $11.1 \pm 0.8 \mathrm{~mm}$ and $301 \pm 98 \mathrm{~mL}$ (11 months); $12.2 \pm 0.6 \mathrm{~mm}$ and $305 \pm 53 \mathrm{~mL}$ (12 months); $12.1 \pm 0.6 \mathrm{~mm}$ and $225 \pm 60 \mathrm{~mL}$ (13 months); $11.6 \pm$ $1.5 \mathrm{~mm}$ and $203 \pm 48 \mathrm{~mL}$ (14 months); $11.8 \pm 1.2 \mathrm{~mm}$ and $138 \pm$ $50 \mathrm{~mL}$ (15 months); $10.8 \pm 1.4 \mathrm{~mm}$ and $101 \pm 42 \mathrm{~mL}$ (16 months); $9.2 \pm 1.5 \mathrm{~mm}$ and $70 \pm 14 \mathrm{~mL}$ (17 months); $9.2 \pm 0.9 \mathrm{~mm}$ and $68 \pm 31 \mathrm{~mL}$ (18 months).

Table 4 shows that the coconut harvest from 30 years-oldtrees and older had total weight fruit and endosperms weight of $1514 \pm 216 \mathrm{~g}$ and $330 \pm 71 \mathrm{~g}$ (9 months); $1401 \pm 240 \mathrm{~g}$ and $320 \pm 52 \mathrm{~g}$ (10 months); $1425 \pm 180 \mathrm{~g}$ and $333 \pm 71 \mathrm{~g}$ (11 months); $1460 \pm 195 \mathrm{~g}$ and $395 \pm 93 \mathrm{~g}$ (12 months); $1373 \pm 206 \mathrm{~g}$ and $390 \pm 100 \mathrm{~g}$ (13 months); $1054 \pm 118 \mathrm{~g}$ and $345 \pm 35 \mathrm{~g}$ (14 months); $1057 \pm$ 
Table 3. The quality of coconut harvest from trees aged 16-25 years (implemented coconut sasi).

\begin{tabular}{|c|c|c|c|c|c|}
\hline Fruit age (months) & $\begin{array}{l}\text { Total weight } \\
\text { fruit }(g) \pm S D\end{array}$ & $\begin{array}{l}\text { Endosperma } \\
\text { weight }(g) \pm \mathrm{SD}\end{array}$ & $\begin{array}{l}\text { Endosperma } \\
\text { thickness }(\mathrm{mm}) \pm \mathrm{SD}\end{array}$ & $\begin{array}{l}\text { Water volume } \\
(\mathrm{mL}) \pm \mathrm{SD}\end{array}$ & $n$ \\
\hline 10 & $1472 \pm 239$ & $301 \pm 19$ & $10.6 \pm 0.6$ & $304 \pm 59$ & 6 \\
\hline 12 & $1422 \pm 53$ & $364 \pm 53$ & $12.2 \pm 0.6$ & $305 \pm 53$ & 6 \\
\hline 13 & $1164 \pm 157$ & $378 \pm 76$ & $12.1 \pm 0.6$ & $225 \pm 60$ & 6 \\
\hline 14 & $1132 \pm 184$ & $360 \pm 107$ & $11.6 \pm 1.5$ & $203 \pm 48$ & 6 \\
\hline 16 & $804 \pm 88$ & $271 \pm 39$ & $10.8 \pm 1.4$ & $101 \pm 42$ & 6 \\
\hline 17 & $794 \pm 67$ & $243 \pm 28$ & $9.2 \pm 1.5$ & $70 \pm 14$ & 6 \\
\hline 18 & $820 \pm 214$ & $273 \pm 62$ & $9.2 \pm 0.9$ & $68 \pm 31$ & 6 \\
\hline
\end{tabular}

$n=$ number of samples in each fruit-age group.

Table 4. The quality of coconut harvest from trees aged $>30$ years (implemented coconut sasi).

\begin{tabular}{|c|c|c|c|c|c|}
\hline $\begin{array}{l}\text { Fruit age } \\
\text { (months) }\end{array}$ & $\begin{array}{l}\text { Total weight } \\
\text { fruit }(g) \pm S D\end{array}$ & $\begin{array}{c}\text { Endosperma } \\
\text { weight }(\mathrm{g}) \pm \mathrm{SD}\end{array}$ & $\begin{array}{c}\text { Endosperma } \\
\text { thickness }(\mathrm{mm}) \pm \mathrm{SD}\end{array}$ & $\begin{array}{l}\text { Water volume } \\
\quad(\mathrm{mL}) \pm \mathrm{SD}\end{array}$ & $n$ \\
\hline 9 & $1514 \pm 216$ & $330 \pm 71$ & $10.9 \pm 1.1$ & $207 \pm 54$ & 6 \\
\hline 11 & $1425 \pm 180$ & $333 \pm 71$ & $11.3 \pm 1.0$ & $238 \pm 65$ & 6 \\
\hline 12 & $1460 \pm 195$ & $395 \pm 93$ & $12.3 \pm 0.6$ & $294 \pm 52$ & 6 \\
\hline 13 & $1373 \pm 206$ & $390 \pm 100$ & $11.4 \pm 0.8$ & $283 \pm 125$ & 6 \\
\hline 15 & $1057 \pm 144$ & $335 \pm 54$ & $11.0 \pm 0.6$ & $140 \pm 42$ & 6 \\
\hline 16 & $826 \pm 104$ & $315 \pm 25$ & $10.1 \pm 1.3$ & $75 \pm 14$ & 6 \\
\hline 17 & $843 \pm 156$ & $269 \pm 55$ & $9.4 \pm 1.5$ & $116 \pm 25$ & 6 \\
\hline 18 & $732 \pm 133$ & $181 \pm 44$ & $6.8 \pm 0.5$ & $112 \pm 41$ & 6 \\
\hline
\end{tabular}

$n=$ number of samples in each fruit-age group.

$144 \mathrm{~g}$ and $335 \pm 54 \mathrm{~g}$ (15 months); $826 \pm 104 \mathrm{~g}$ and $315 \pm 25 \mathrm{~g}$ (16 months); $843 \pm 156 \mathrm{~g}$ and $269 \pm 55 \mathrm{~g}$ (17 months); $732 \pm 133 \mathrm{~g}$ and $181 \pm 44 \mathrm{~g}$ (18 months). Menawhile, the endosperms thickness and water volume for each fruit age were about $10.9 \pm 1.1 \mathrm{~mm}$ and $207.7 \pm 54.9 \mathrm{~mL}$ (9 months); $11.3 \pm 0.9 \mathrm{~mm}$ and $285 \pm 75 \mathrm{~mL}$ (10 months); $11.3 \pm 1.0 \mathrm{~mm}$ and $238 \pm 65 \mathrm{~mL}$ (11 months); $12.3 \pm$ $0.6 \mathrm{~mm}$ and $294 \pm 52 \mathrm{~mL}$ (12 months); $11.4 \pm 0.8 \mathrm{~mm}$ and $283 \pm$ $125 \mathrm{~mL}$ (13 months); $11.4 \pm 0.9 \mathrm{~mm}$ and $171 \pm 47 \mathrm{~mL}$ (14 months); $11.0 \pm 0.6 \mathrm{~mm}$ and $140 \pm 42 \mathrm{~mL}$ (15 months); $10.1 \pm 1.3 \mathrm{~mm}$ and $75 \pm 14 \mathrm{~mL}$ (16 months); $9.4 \pm 1.5 \mathrm{~mm}$ and $116 \pm 25 \mathrm{~mL}$ ( 17 months); $6.8 \pm 0.5 \mathrm{~mm}$ and $112 \pm 41 \mathrm{~mL}$ (18 months).

The results obtained indicated that yields on the 16-25years-old trees had a total weight of fruit of 794-1522 g, a weight of endosperms of 243-378 g, a thickness of the coconut endosperm of 9.2-12.2 mm and a volume of water of $68-305 \mathrm{~mL}$ (Tab. 3). Yields on $>30$-years-old trees group had a total fruit weight of 732-1514 g, an endosperm weight of 181-395 g, a coconut endosperm thickness of $6.8-12.3 \mathrm{~mm}$ and a water volume of 75-294 mL (Tab. 4). These data show that quality of coconut fruit on both age groups of tree tended to be the same.

The total weight fruit in both age groups decreased as fruitage increased. Unripe coconut fruit is heavier because it is affected by the weight of coir and the abundance of coconut water. When entering the ripening fruit period, the weight of the fruit declines because of the shrinkage of coir weight and reduced coconut water volume, but the weight of endosperm increases (Darwis, 1986; Suhardiyono, 1995).

The weight of the endosperm is optimal on the ripe fruit. The data in Tables 3 and 4 show that the highest endosperm weight is found in ripe coconut (12-13 months), whereas the lowest endosperm is found in overripe coconuts (17-18 months), indicating that the weight of the endosperm decreases in the overripe fruit. Coconut does not have a dormancy period, therefore, when the fruit ripens the process of direct germination is also started (Sankaran et al., 2012). During germination, the haustorium grows larger and increases weight while the weight of the endosperm decreases (Soedijanto and Sianipar, 1984; Su'I, 2010; Konan et al., 2017).

The weight of the endosperm is related to endosperm thickness. As the endosperm solidifies, the thickness of the endosperm increases (Assa et al., 2010). Crop data on both age groups shows that ripe coconuts have a thicker endosperm than unripe and overripe fruit. The thickness of the endosperm is not optimal yet on the unripe fruit because the process of endosperm formation is still ongoing. Entering the ripening period, the endosperm increases thickness.

After the fruit has ripened, the thickness of the coconut endosperm decreases as the fruit continues to age. This is 
because the coconut endosperm is decomposed by enzymes released by the haustorium for institutional development in the formation of new individuals (Soedijanto and Sianipar, 1984; Sankaran et al., 2012; Konan et al., 2017). Thus, the harvesting of overripe coconuts harms the farmers because the thickness of the coconut endosperm has been reduced due to the germination process.

Another component of coconut fruit is coconut water. Coconut water is a nutrient-rich and sterile liquid endosperm (Haseena et al., 2010; Appaiah et al., 2015). The volume of coconut water decreases as the fruit begins to ripen. Therefore, the reduced volume of water in the coconut is used as a marker to indicate that the coconut is ripening (Soedijanto and Sianipar, 1984). The data in Tables 3 and 4 show that at the beginning of the maturity of the fruit the volume of coconut water is still in abundance but decreases as the fruit ripens. In Table 4, the mean coconut water volume appears to be fluctuating. This is because the randomly selected coconut fruit from the fruit-age group has a varied fruit and seed size (endocarp and endosperm). Coconut fruit with a relatively small seed size has a smaller volume of water. Samples of coconuts extracted from the 16-months-old fruit group had relatively smaller fruit and seed sizes with less water volume than the 17-months-old fruit group (Tab. 4). In spite of the farmers being paid by the weight of copra, these results should be confirmed by determining the oil content in albumen; however it is well known that optimal ripeness also corresponds to the maximum of oil yield.

\subsection{Improving coconut sasi practice}

All informants stated that the coconut sasi so far had effectively guaranteed the coconut harvest quantity. However, quantitative results indicated that the coconut sasi implementation had a negative effect on the quality of the coconut harvest. The duration of the sasi caused the harvesting to be incompatible with the coconut fruit-ripening period. It was evident that the farmers had little knowledge concerning the biological works of coconut, especially about reproduction and fruit maturity. Their knowledge is still limited to traditional coconut cultivation obtained from their ancestors, so that the current agricultural activity is simply passing on what their ancestors have implemented.

Local wisdom does need to be conserved as it benefits local communities, but local wisdom practices need to be studied more deeply to determine and correct existing weaknesses in local wisdom practices. Berkes et al. (2000) stated that not all traditional practices and belief systems are ecologically appropriate, as some become unsuitable along with changes in existing conditions so that traditional practices are not ecologically wise. The results of this study indicate that coconut sasi for six months is not biologically wise because it has delayed the best harvest time for coconuts and degrades the quality of the harvested.

The concept of local wisdom refers to the system of knowledge, technology and management by traditional societies developed under certain conditions to fulfill life requirements in accordance with existing environmental conditions. Traditional knowledge is dynamic, evolving locally and adapting specifically to the requirements of its users under certain conditions (Kamagenge, 2012). Based on this concept, the implementation of local wisdom of coconut sasi in South Buru can be improved without reducing the value of the sasi itself. The application of coconut sasi should be adapted to the proper and compatible reproduction pattern to the age of maturity of coconut fruit. Farmers need to modify the sasi period to work synergistically with the biological timing of coconut ripening. This improvement is intended to ensure that the local wisdom practice of coconut sasi is not only effective for maintaining the quantity of coconuts but also to improve the quality of coconut crops.

People cannot blame the ancestors who passed on the local wisdom of sasi. Indeed, sasi was made within the limits of knowledge for securing the production of crops and other natural resources in the past. The development of science is expected to be the basis for improving the implementation of coconut sasi in South Buru to become wiser and provide greater benefits for farmers. Local wisdom uses the past as an inspiration to formulate new knowledge and skills so that people can live in harmony with their ever-changing environment.

\section{Conclusion}

Coconut sasi is effective for securing the coconut fruit before the harvesting period. However, the implementation of a six-month coconut sasi period is not biologically compatible because it postpones the best harvest time for coconuts and negatively affects the quality of the crops. It is recommended that the implementation of coconut sasi by farmers in South Buru can be adjusted with biological reproduction patterns and coconut maturity age.

Acknowledgements. The authors would like to thank the Directorate of Research and Community Service, the Directorate General for Research and Development, the Ministry of Research, Technology and Higher Education Republic of Indonesia who has provided funding support for this research. The author also thanks Dr. Purnomo, M.S. who has read and provided input for this paper.

\section{References}

Appaiah P, Sunil L, Kumar PKP, Krishna AGG. 2015. Physicochemical characteristics and stability aspects of coconut water and kernel at different stages of maturity. J Food Sci Tech 52(8): 5196-5203.

Assa RR, Konan KJL, Prades A, Nemlin J, Koffi E. 2010. Physicochemical characteristics of kernel during fruit maturation of four coconut cultivars (Cocos nucifera L.). Afr J Biotechnol 9 (14): 2136-2144.

Badan Pusat Statistik (BPS) Kabupaten Buru Selatan [South Buru Regency Statistics Agency (BPS)]. Kabupaten Buru Selatan dalam angka 2017 [South Buru Regency in number 2017]. Namrole: BPS Kabupaten Buru Selatan, 2017, pp. 132-133.

Berkes F, Colding J, Folke C. 2000. Rediscovery of traditional ecological knowledge as adaptive management. Ecol Implement 10(5): 1251-1262.

Darwis SN. Tanaman kelapa dan lingkungan pertumbuhannya [Coconut plants and their growth environment]. Manado: Departemen Pertanian [Agriculture Department], 1986, pp.97-124. 
Dransfield J, Uhl NW, Asmussew CB, Baker WJ, Harley MM, Lewis CE. Genera palmarum: The evolution and classification of palms. United Kingdom: Kew Publication Royal Botanic Gardens, 2008, pp. 416-419.

Haseena M, Kasturi BKV, Padmanabhan S. 2010. Post-harvest quality and shelf-life of tender coconut. J Food Sci Tech 47(6): 686-689.

Hendaryati DD, Arianto Y, eds. Statistik Perkebunan Indonesia Komoditas Kelapa 2016-2018. Jakarta: Sekretariat Direktorat Jendral Perkebunan, Direktorat Jendral Perkebunan, Kementerian Pertanian, 2017, $7 \mathrm{p}$.

Henley D. 2008. Natural resource management: Historical lessons from Indonesia. Hum Ecol 36(2): 273-290.

Kamagenge V. Mobilizing local expertise through networking and empowerment. In: Davies J, ed. Conservation and sustainable development: Linking practice and policy in Eastern Africa. Ottawa (Canada): Routledge IDRC, 2012, pp. 39-54.

Keraf AS. Etika lingkungan hidup [Environmental ethics]. Jakarta: Kompas, 2010, pp. 359-390.

Kissya E. Sasi aman haru-ukui. Jakarta: Yayasan Sejati, 1993, pp. 5-7

Konan BR, Assa RR, Kouassi KN, Konan KJL, Amani NG. 2017. Variation of physicochemical parameters of coconut (Cocos nucifera L.) haustorium during germination. Int J Agron Agric Res 10(5): 17-25.
Marfai MA. Pengantar etika lingkungan dan kearifan lokal [Introduction to environmental ethics and local wisdom]. Yogyakarta: Universitas Gadjah Mada Press, 2012, pp. 33-45

Mitchell B, Setiawan B, Rahmi DH. Pengelolaan sumberdaya dan lingkungan [Management of resources and environment]. Yogyakarta: Universitas Gadjah Mada Press, 2010, pp. 301-310.

Pathiraja PMEK, Fernando MTN, Abeysekera AWDR. 2007. Economics of monthly picking viz bimonthly picking of coconuts: An economic analysis. Plantology 83(974): 329-334.

Sankaran M, Damodaran V, Singh DR, Jerard BA. 2012. Vivipary in cocos nucifera L. var Andaman green dwarf. Curr Sci 103(10): 1139-1140.

Simpala MM, Kusuma A. Save the tree of life: Potensi sektor kelapa Indonesia [The potential of the Indonesian coconut sector]. Bogor: Bypass, 2015, pp. 29-50.

Soedijanto S, Sianipar RRM. Kelapa [Cocounut]. Jakarta: CV Yasaguna, 1984, pp. 24-43.

Suhardiyono L. Tanaman kelapa: budidaya dan pemanfaatannya [Coconut plants: cultivation and utilization]. Yogyakarta: Kanisius, 1995, pp. 16-24.

Su'I M. 2010. Perubahan fisiologis buah kelapa selama germinasi [Physiological changes of coconuts during germination]. Agrika 4 (1): $60-66$.

Thampan PK. Handbook on coconut palm. New Delhi: Mohan Primlani, Oxford \& IBH Publishing Co, 1981, pp. 1-25.

Cite this article as: Tuhumuri E, Sancayaningsih RP, Setiaji B, Usman S. 2020. The implementation and effect of sasi on coconut (Cocos nucifera L.) harvest products in southern Buru, Indonesia. OCL 27: 3. 